\title{
Compost, leonardite, and zeolite impacts on soil microbial community under barley crops
}

\author{
José Luis Moreno $^{1 *}$, Sara Ondoño ${ }^{1,2}$, Irene Torres $^{1}$, Felipe Bastida $^{1}$
}

${ }^{1}$ Department of Soil Conservation and Organic Resources Management, Centro de Edafología y Biología Aplicada del Segura (CEBAS-CSIC), P.O. Box 164, 30100-Espinardo, Murcia, Spain. ${ }^{2}$ Department of Agricultural Science and Technology, Faculty of Agricultural Engineering of Technical University of Cartagena, Paseo Alfonso XIII 48, 30203-Cartagena, Spain. *Corresponding author: jlmoreno@cebas.csic.es

\begin{abstract}
There is little information about the potential effects of compost and zeolite or zeolite with leonardite as soil amendments in barley cultivation. Thus in this study, the following objectives were proposed: i) to compare the effects of the addition of compost, alone or simultaneously with zeolite, and of the addition of leonarditeenriched zeolite with those of the conventional NPK fertilization used in barley cultivation, on the soil nutritional status, microbial community structure, and enzyme activity in different stages of barley cultivation; and ii) to establish relationships between the different soil parameter trends, soil microbial community structure, and barley crop yield. In the field experiment carried out with a barley crop, the alternative fertilization treatments tested had an overall positive effect, in comparison with conventional fertilization with a mineral NPK fertilizer, when soil quality parameters, the nutritional level and yield of the barley crop were analyzed. Zeolite with leonardite increased barley yield in comparison with the compost treatments, either with zeolite or without, but had an excessive contribution to the water soluble contents of $\mathrm{Na}$ and $\mathrm{N}$ in soil. So, using environmental and agronomic criteria, the most rational action would be the use of compost in agriculture.
\end{abstract}

Keywords: Compost, leonardite, zeolite, enzyme activities, PLFA biomarkers, soil fertilization 


\section{Introduction}

In the Mediterranean countries of Southern Europe, organic matter depletion in soils is undoubtedly the main soil degradation process in arid and semi-arid conditions (Diacono \& Montemurro, 2010). Common agricultural practices such as excessive use of agro-chemicals, deep tillage, and luxury irrigation have degraded soils, polluted water resources, and contaminated the atmosphere (Wells et al., 2000). The consequence of these unsuitable practices is the soil degradation that limits soil productivity in Mediterranean agroecosystems. Simultaneously, there is increasing and widespread organic waste production. New and sustainable strategies for organic waste management, in combination with the adoption of European policies at national levels, have minimized their disposal in landfills and increased their safe recycling in soil as organic amendments. The application of quality assured composts in crop cultivation may significantly contribute to yield efficiency, soil conservation, and soil fertility improvement due to their high content of stable $\mathrm{C}$ from humic substances, good phosphorus and potassium fertilization efficiency, slow release of available $\mathrm{N}$ forms, and liming effect (ECN 2010). Furthermore, it is well documented that compost amendment increases the biomass and activity of the soil microbial community, benefiting soil fertility (Bastida et al., 2008).

Leonardite is an organic material found in soft, coal-like deposits that occur at shallow depths and it is a concentrated form of humic and fulvic acids, used in agricultural production (Ayuso et al., 1997). Zeolites, naturally occurring groups of minerals containing a cage-like structure, may promote plant growth by enhancing nutrient availability, soil conditioning, and soil moisture holding capacity (Polat et al., 2004) - thereby providing higher yields and better quality of crops (Ippolito, 2011). The adsorption of humic extracts obtained from leonardite on zeolite gives an organic-mineral complex which may be used in crop cultivation due to its properties as a soil fertilizer and plant growth improver. However, there is little information about the interactions of both composts and humic extracts obtained from leonardite with a natural zeolite (clinoptilolite), and their potential synergistic effects as soil amendments in barley cultivation. Thus, it can be hypothesized that: i) manure compost, as a single soil amendment or in combination with zeolite, or zeolite enriched with a humic extract of leonardite could be utilized as substitutes for conventional mineral fertilizers in barley cultivation; ii) there will be relationships between the enzyme activities, nutritional status, and microbiological community structure of the soil under a barley crop and the grain production and plant nutritional level. In order to test these hypotheses the following objectives were proposed: i) to compare the effects of the addition of compost, alone or simultaneously with zeolite, and of the addition of leonardite-enriched zeolite with those of the conventional NPK fertilization used in barley cultivation, on the soil nutritional status, microbial community structure, and enzyme activity in different stages of barley cultivation; and ii) to establish relationships between the different soil parameter trends, soil microbial community structure, and barley crop yield.

\section{Materials and Methods}

\subsection{Trial location and climatic and soil conditions}

The experimental field was located in the province of Albacete (SE Spain), in the Experimental Farm of "Las Tiesas" which is managed by the Agricultural and Technical Institute of the Provincial Government (ITAP). Its geographical coordinates are $2^{\circ}$ 
5' 10" West (longitude) and 39 3' 30" North (latitude), with a height above sea level of $695 \mathrm{~m}$. The predominant climate in the area is continental with an average annual rainfall of $320 \mathrm{~mm}$ and annual average temperature of $14{ }^{\circ} \mathrm{C}$. The soil is classified as a Petrocalcic Calcixerepts and is shallow, about 40 $\mathrm{cm}$ deep, being limited by a petrocalcic horizon. The main characteristics of the soil are shown in Table 1.

Table 1. Initial characterization of the soil in the experimental plot

\begin{tabular}{|c|c|}
\hline Parameter (units) & Value \\
\hline Sand $\left(\mathrm{g} \mathrm{kg}^{-1}\right)$ & 220 \\
\hline Silt $\left(\mathrm{g} \mathrm{kg}^{-1}\right)$ & 440 \\
\hline Clay $\left(\mathrm{g} \mathrm{kg}^{-1}\right)$ & 290 \\
\hline $\mathrm{pH}$ & 8.5 \\
\hline $\mathrm{EC}\left(\mathrm{mS} \mathrm{cm}^{-1}\right)$ & 0.48 \\
\hline $\mathrm{Cl}^{-}\left(\mathrm{mg} \mathrm{kg}^{-1}\right)$ & 21.0 \\
\hline $\mathrm{SO}_{4}{ }^{=}\left(\mathrm{mg} \mathrm{kg}^{-1}\right)$ & 630 \\
\hline $\mathrm{OM}\left(\mathrm{g} \mathrm{kg}^{-1}\right)$ & 18.0 \\
\hline$N\left(\mathrm{~g} \mathrm{~kg}^{-1}\right)$ & 1.2 \\
\hline $\mathrm{C} / \mathrm{N}$ & 10.3 \\
\hline $\mathrm{NO}_{3}{ }^{-}-\mathrm{N}\left(\mathrm{mg} \mathrm{kg}^{-1}\right)$ & 11.2 \\
\hline $\mathrm{NH}_{4}{ }^{+}-\mathrm{N}\left(\mathrm{mg} \mathrm{kg}^{-1}\right)$ & 0.65 \\
\hline Available $\mathbf{P}\left(\mathrm{mg} \mathrm{kg}^{-1}\right)$ & 15.0 \\
\hline Total carbonates $\left(\mathrm{g} \mathrm{kg}^{-1}\right)$ & 333 \\
\hline Active lime $\left(\mathrm{g} \mathrm{kg}^{-1}\right)$ & 108 \\
\hline Available $\mathrm{K}\left(\mathrm{meq} \mathrm{kg}^{-1}\right)$ & 10.9 \\
\hline Available $\mathrm{Na}\left(\mathrm{meq} \mathrm{kg}{ }^{-1}\right)$ & 17.3 \\
\hline Available $\mathrm{Ca}\left(\mathrm{meq} \mathrm{kg}^{-1}\right)$ & 549 \\
\hline Available $\mathrm{Mg}\left(\right.$ meqkg $\left.^{-1}\right)$ & 62.4 \\
\hline $\mathrm{K} / \mathrm{Mg}$ & 0.17 \\
\hline $\mathrm{Ca} / \mathrm{Mg}$ & 9.0 \\
\hline
\end{tabular}

\subsection{Materials used as fertilizers or amendments}

The materials used in this fertilization assay were: manure compost, zeolite, zeolite supplemented with humic extract obtained from leonardite, and a mineral complex, NPK 8-24-8 type (from the company "Fertiberia S.A."), used conventionally for growing barley and which served as the fertilization control.
The composted manure was supplied by the company "Orgánicos Pedrin S.L.", and it was produced by composting goat and sheep manure with cereal straw. The chemical analysis of this organic amendment is shown in Table 2. The zeolite used in this assay was supplied by the company "Zeocat Soluciones Ecológicas S.L.U.”. It is a naturally occurring zeolite with $85-95 \%$ clinoptilolite. The zeolite enriched with $20-25 \%$ leonardite was also supplied by the latter company. Besides the properties of the zeolite, the leonardite provides mainly humic and fulvic acids and also potassium to soil. Moreover, the humic acids have a hormonelike action on the plants, favoring their development (Ayuso et al., 1997). The chemical properties of this organic amendment are shown in Table 2. These materials were applied to the soil by basal dressing in late December 2014 and were incorporated into the soil by tillage; the soil was then irrigated to moisten it and to activate biogeochemical cycles.

Table 2. Chemical characteristics of the materials used for soil amendment.

\begin{tabular}{lcc}
\hline & $\begin{array}{c}\text { Zeolite with } \\
\text { leonardite }\end{array}$ & $\begin{array}{c}\text { Manure } \\
\text { compost }\end{array}$ \\
\hline $\mathrm{TOC}\left(\mathrm{g} \mathrm{kg}^{-1}\right)$ & 20.6 & 268.8 \\
$\mathrm{~N}\left(\mathrm{~g} \mathrm{~kg}^{-1}\right)$ & 9.8 & 21.8 \\
$\mathrm{Al}\left(\mathrm{g} \mathrm{kg}^{-1}\right)$ & 19.1 & 4.5 \\
$\mathrm{~B}\left(\mathrm{mg} \mathrm{kg}^{-1}\right)$ & 45.2 & 44.83 \\
$\mathrm{Ca}\left(\mathrm{g} \mathrm{kg}^{-1}\right)$ & 9.1 & 74.3 \\
$\mathrm{Cd}\left(\mathrm{mg} \mathrm{kg}^{-1}\right)$ & 0.86 & $<0.5$ \\
$\mathrm{Cu}\left(\mathrm{mg} \mathrm{kg}^{-1}\right)$ & 2.08 & 23.66 \\
$\mathrm{Fe}\left(\mathrm{mg} \mathrm{kg}^{-1}\right)$ & 6421 & 17002 \\
$\mathrm{~K}\left(\mathrm{~g} \mathrm{~kg}^{-1}\right)$ & 16.0 & 37.8 \\
$\mathrm{Mg}\left(\mathrm{g} \mathrm{kg}^{-1}\right)$ & 2.5 & 9.1 \\
$\mathrm{Mn}\left(\mathrm{mg} \mathrm{kg}^{-1}\right)$ & 162.52 & 272.08 \\
$\mathrm{Na}\left(\mathrm{g} \mathrm{kg}^{-1}\right)$ & 5.7 & 2.0 \\
$\mathrm{Ni}\left(\mathrm{mg} \mathrm{kg}^{-1}\right)$ & 6.24 & 5.53 \\
$\mathrm{~Pb}\left(\mathrm{mg} \mathrm{kg}^{-1}\right)$ & 32.4 & 6.09 \\
$\mathrm{P}\left(\mathrm{g} \mathrm{kg}^{-1}\right)$ & 0.4 & 5.3 \\
$\mathrm{~S}\left(\mathrm{~g} \mathrm{~kg}^{-1}\right)$ & 2.3 & 26.3 \\
$\mathrm{Zn}\left(\mathrm{mg} \mathrm{kg}^{-1}\right)$ & 2960 & 74.04 \\
$\mathrm{NH}{ }^{+}\left(\mathrm{mg} \mathrm{kg}^{-1}\right)$ & 183.25 & 335.70 \\
$\mathrm{NO}{ }^{-}\left(\mathrm{mg} \mathrm{kg}^{-1}\right)$ & 17.88 & 793.63 \\
\hline
\end{tabular}




\subsection{Experimental design}

In this trial four treatments with four replicates each were set up in a randomized, complete block design. The minimum experimental unit was a plot of $28 \mathrm{~m}^{2}$, divided into two equal subplots. In one of these, samplings of soil and plants were made throughout the growing season, while the other was reserved for the final harvest. The treatments tested and doses applied to the soil were: 1) the MC treatment was a basal dressing with manure compost at a dose of $38 \mathrm{t} \mathrm{ha}^{-1} ; 2$ ) the MCZ treatment was identical to MC, but also zeolite was simultaneously applied at a dose of $90 \mathrm{t} \mathrm{ha}^{-1}(3 \%)$; 3 ) the MF treatment was a conventional mineral fertilization, serving as an assay control, and consisted of a basal dressing using an NPK complex (8-24-8) which was added to the soil at the recommended dose $(0.35 \mathrm{t}$ $\mathrm{ha}^{-1}$ ) for the barley crop; 4) the ZL treatment consisted of a basal dressing with zeolite supplemented with leonardite at a dose of $75 \mathrm{tha}^{-1}$. The top-dressing dose was divided into two halves, applying the first in the tillering phase of barley and the second in the stem extension stage. The top-dressing dose applied was $90 \mathrm{~N}$ fertilizer units (NFU), using calcium and ammonium nitrate $(27 \%)$. The top-dressing dose of the tested organic treatments (MC, MCZ, and ZL) was equivalent to a quarter of that applied in the conventional mineral treatment (MF).

\subsection{Phenology, farming, and soil samplings during} the barley cultivation

On 13 January 2015 the plots were sown with barley seeds (variety Pewter) at $190 \mathrm{~kg} \mathrm{ha}^{-1}\left(400\right.$ seeds $\left.\mathrm{m}^{-2}\right)$. The barley emergence was recorded on 16 February 2015, the tillering on 30 March, the stem extension on 24 April, and the coming into ear on 10 May. The crop developed free of pests and diseases due to the application of herbicides (POSTA-sulfonylurea, PLAT-
FORM-carfentrazone, and LOGRAN-sulfonylurea) at the recommended doses. Irrigation was applied by spraying. For this growth cycle, the water needs of the crop were $464 \mathrm{~mm}$ and precipitation was 115 $\mathrm{mm}$. Three soil samplings were carried out along the cultivation: $\mathrm{T} 0, \mathrm{~T} 1$, and $\mathrm{T} 2$. The $\mathrm{T} 0$ soil sampling was carried out 15 days after basal dressing of the soil with the different treatments (8 January); T1 was carried out at the end of the emergence phase of the barley crop (10 March); and T2 at the start of stem extension (27 April). In each plot, three subsamples were taken from the $0-20 \mathrm{~cm}$ soil layer and mixed to form a composite sample. The samples were taken to the laboratory, dried at room temperature, and sieved through a 2-mm mesh. Samples were kept in a chamber at $5{ }^{\circ} \mathrm{C}$ until chemical and enzyme analysis and at $-20{ }^{\circ} \mathrm{C}$ for fatty acids analysis. The barley crop was harvested on $1 \mathrm{July}$, and then both the aboveground biomasses (grain and straw weight) produced in every treatment and its $\mathrm{N}$ content were determined.

\subsection{Chemical analyses}

For elemental analysis of soil samples, acid digestion of samples or extraction with distilled water was conducted to determine the total and soluble fraction concentrations, respectively, of macro and micronutrients, using an ICP-OES analyzer (Iris Intrepid II XDL, Thermo Scientific). The total contents of $\mathrm{C}$, organic $\mathrm{C}$, and $\mathrm{N}$ were determined by a CN Flash2000 (Thermo Scientific) analyzer; the water-soluble fractions of these elements were determined by a $\mathrm{CN}$ analyzer for liquid samples ((Multi N/C 3100, Analytikjena, Germany)). The anion content in the soil was determined from a filtered aqueous extract, using an ionic chromatograph. The ammonium concentration in soil were determined using a $1 \mathrm{M} \mathrm{KCl}$ solution, in a ratio 1:10 soil:solution, to extract the available fraction of this cation and then 
determined by a colorimetric method (Keeney and Nelson, 1982).

Collection of plant biomass samples in each plot was conducted using a framework of $0.5 \times 0.5 \mathrm{~m}$. For each of these samples a count of the number of ears was made, and fresh weight and oven-dry weight were recorded. For elemental analysis, the straw and grain samples were ground; then, they were submitted to acid digestion using a microwave oven and elemental concentrations were determined by ICP-OES.

\subsection{Assay methods of soil enzyme activities}

Enzyme activities were determined by a microplate method, modified from the method of Allison and Jastrow (2006), and each enzyme activity was tested using specific substrates. A 96-well microplate was used for each enzyme activity. For this, an extract of each soil sample was made with Tris (pH 7) and was homogenized using a mixer. From this extract, aliquots were taken in triplicate and were placed in the wells of the microplate, adding the corresponding substrate. In the same plate, parallel controls were prepared without substrate, in triplicate, and each plate was incubated at $28{ }^{\circ} \mathrm{C}$ for the time corresponding to each enzyme activity. The substrates were $6 \mathrm{mM}$ 4-nitrophenyl $\beta$-D-cellobioside for cellobiohydrolase (CBH), $6 \mathrm{mM}$ 4-nitrophenyl N-acetyl- $a$-D-glucosaminide for $\mathrm{N}$ acetyl glucosaminidase or quitinase (NAG), $15 \mathrm{mM}$ $p$-nitrophenol $\beta$-D-glucopyranoside for $\beta$-glucosidase (BGA), $5 \mathrm{mM}$ leucine $p$-nitroanilide pre-dissolved in a small volume of acetone for leucine aminopeptidase (LEU), $20 \mathrm{mM}$ p-nitrophenol phosphate for alkaline phosphatase (APA), and $50 \mathrm{mM}$ pyrogallol for polyphenoloxidase (PPO) and peroxidase (POD). For the latter enzyme activity (POD), $10 \mathrm{ml}$ of $30 \% \mathrm{H}_{2} \mathrm{O}_{2}$ were added together with the substrate. The incubation times used for the enzyme activity determinations were: $1 \mathrm{~h}$ for BGA and APA, $2 \mathrm{~h}$ for PPO and POD, 4 $\mathrm{h}$ for LEU, and $6 \mathrm{~h}$ for NAG and CBH. After that, the microplates were centrifuged and $100 \mathrm{ml}$ of supernatant from each well were transferred to a new microplate. For BGA, APA, CBH, and NAG, $5 \mathrm{ml}$ of 1 $\mathrm{M} \mathrm{NaOH}$ were added in order to stop the enzymatic reaction. The absorbance of the solution in each well was read with a TECAN Infinite M200 spectrophotometer at the following wavelengths: $410 \mathrm{~nm}$ for BGA, APA, NAG, and CBH; $405 \mathrm{~nm}$ for LEU; 460 $\mathrm{nm}$ for PPO and POD. Urease activity (URA) was determined as the $\mathrm{NH}_{4}^{+}$released in the hydrolytic reaction using urea as substrate and borate buffer $(\mathrm{pH}$ =10) (Kandeler and Gerber, 1988).

\subsection{Phospholipids extraction from soil and their analysis}

Phospholipids were extracted from $6 \mathrm{~g}$ of soil using a chloroform-methanol extraction based on the method of Bligh and Dyer (1959). They were fractionated and quantified using the procedure described by Frostegard et al., (1993).

The complete dried FAME fraction was dissolved in isooctane containing $0.23 \mathrm{mg} \mathrm{ml}^{-1}$ of 21:0 FAME as internal standard. The analysis was performed using a Trace Ultra Thermo Scientific gas chromatograph fitted with a $60-\mathrm{m}$ capillary column (Thermo TRFAME $60 \mathrm{~m} \times 0.25 \mathrm{~mm}$ ID $\times 0.25 \mu \mathrm{m}$ film), using helium as carrier gas. The following fatty acids are characteristic bacterial fatty acids and were chosen as bacterial biomarkers: i15:0, a15:0, 15:0, i16:0,

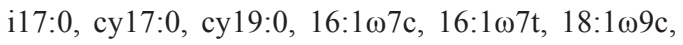

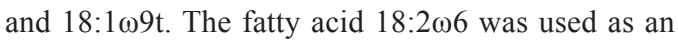
indicator of fungal biomass. The Gram-positive representative fatty acids used were i15:0, a15:0, i16:0, and i17:0. The Gram-negative fatty acids used were

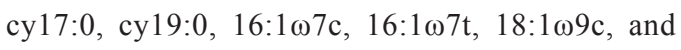
$18: 1 \omega 9 \mathrm{t}$. 


\subsection{Statistical analysis of data}

The data were submitted to ANOVA of repeated measures, with a Tukey multiple comparison test in order to establish honestly significant differences (HSD) between treatments at a significance level of $\mathrm{P}<0.05$. Simultaneously, this statistical analysis establishes the significance of differences in the values with respect to the value measured at the T0 sampling time, as a consequence of the time factor, for a given treatment. Additionally, a multivariate statistical method (factorial analysis) was used to determine relationships between the enzyme activities and nutrient content in soil and also the similarities between treatments at every sampling time.

The relative abundances of fatty acids were submitted to another factorial analysis to determine changes in the structure of the soil microbial community. In order to establish relationships between the total and specific PLFA contents used as biomarkers of different microbial groups, enzyme activities, and the the nutrient levels in the soil for all sampling times, a correlation analysis was carried out to obtain the Spearman correlation coefficient and its significance level for every pair of variables. All these methods of data analysis were performed using the software IBM-SPSS statistics 23.

\section{Results}

\subsection{Total concentrations and water soluble fractions of chemical elements in the soil}

Fifteen days after basal dressing of the soil, significant differences between treatments were detected for the total soil concentrations of $\mathrm{Ca}, \mathrm{B}, \mathrm{Na}$, and $\mathrm{P}$ (Table 3). The total concentrations of $\mathrm{B}$ and $\mathrm{Na}$ were significantly higher after the application of the ZL treatment than for the other treatments assayed. The Ca concentration was significantly higher in the MF and ZL treatments than in MCZ. However, the P concentration was significantly higher in treatment MCZ than in MF.

Table 3. Average and error standard of total concentrations of elements measured in every treatment after 15 days of basal dressing (T0 sampling). For each element, not shared letters indicate honestly significant differences (HSD) between treatments according to post-hoc test of Tuckey $(\mathrm{P}<0.05)$

\begin{tabular}{lllll}
\hline & Compost & $\begin{array}{l}\text { Compost and } \\
\text { zeolite }\end{array}$ & $\begin{array}{l}\text { Mineral } \\
\text { fertilization }\end{array}$ & $\begin{array}{l}\text { Zeolite with } \\
\text { leonardite }\end{array}$ \\
\hline $\mathrm{Ca}\left(\mathrm{g} \mathrm{kg}^{-1}\right)$ & $120 \pm 8.0 \mathrm{ab}$ & $102 \pm 4.0 \mathrm{a}$ & $138 \pm 8.0 \mathrm{~b}$ & $134 \pm 4.0 \mathrm{~b}$ \\
$\mathrm{Fe}\left(\mathrm{g} \mathrm{kg}^{-1}\right)$ & $20.3 \pm 00.8 \mathrm{a}$ & $20.4 \pm 0.4 \mathrm{a}$ & $20.6 \pm .0 .7 \mathrm{a}$ & $19.4 \pm 0.7 \mathrm{a}$ \\
$\mathrm{K}\left(\mathrm{g} \mathrm{kg}^{-1}\right)$ & $10.1 \pm 0.5 \mathrm{a}$ & $10.4 \pm 0.4 \mathrm{a}$ & $9.8 \pm 0.3 \mathrm{a}$ & $10.5 \pm 0.1 \mathrm{a}$ \\
$\mathrm{S}\left(\mathrm{g} \mathrm{kg}^{-1}\right)$ & $1.7 \pm 0.0 \mathrm{a}$ & $1.8 \pm 0.0 \mathrm{a}$ & $1.5 \pm 0.1 \mathrm{a}$ & $1.7 \pm 0.1 \mathrm{a}$ \\
$\mathrm{P}\left(\mathrm{mg} \mathrm{kg}^{-1}\right)$ & $485 \pm 49 \mathrm{ab}$ & $509 \pm 9 \mathrm{~b}$ & $379 \pm 9 \mathrm{a}$ & $409 \pm 16 \mathrm{ab}$ \\
$\mathrm{Na}\left(\mathrm{mg} \mathrm{kg}^{-1}\right)$ & $285 \pm 4 \mathrm{a}$ & $303 \pm 14 \mathrm{a}$ & $265 \pm 6 \mathrm{a}$ & $871 \pm 47 \mathrm{~b}$ \\
$\mathrm{~B}\left(\mathrm{mg} \mathrm{kg}^{-1}\right)$ & $22.7 \pm 1.0 \mathrm{a}$ & $22.5 \pm 0.4 \mathrm{a}$ & $22.6 \pm 0.6 \mathrm{a}$ & $27.9 \pm 0.9 \mathrm{~b}$ \\
$\mathrm{Mg}\left(\mathrm{g} \mathrm{kg}^{-1}\right)$ & $7.2 \pm 0.3 \mathrm{a}$ & $7.2 \pm 0.2 \mathrm{a}$ & $7.7 \pm 0.02 \mathrm{a}$ & $7.2 \pm 0.2 \mathrm{a}$ \\
$\mathrm{Mn}\left(\mathrm{mg} \mathrm{kg}^{-1}\right)$ & $355 \pm 14 \mathrm{a}$ & $366 \pm 21 \mathrm{a}$ & $355 \pm 4 \mathrm{a}$ & $332 \pm 10 \mathrm{a}$ \\
\hline
\end{tabular}


Regarding the water soluble fraction of nutrients in soil, the $\mathrm{Mg}, \mathrm{K}, \mathrm{S}$, and $\mathrm{Ca}$ concentrations were significantly higher in the two treatments with compost (MC and MCZ) than in MF or ZL, at the T0 sampling (Figure 1). However, the water soluble fraction of $\mathrm{Na}$ was significantly higher in ZL than in the other treatments at T0. At the second soil sampling (T1), the water soluble fractions of $\mathrm{Mg}, \mathrm{K}$, and $\mathrm{Na}$ showed similar trends than at $\mathrm{T} 0$. There were no significant differences in the water soluble fractions of $\mathrm{Ca}$ or $\mathrm{S}$ between treatments $\mathrm{MC}$, $\mathrm{MCZ}$, and ZL, their concentrations being significantly higher than in MF. At the third sampling (T2), the water soluble fractions of $\mathrm{Mg}$ and $\mathrm{Ca}$ were more similar among the treatments. The water soluble fraction of $\mathrm{Na}$ showed a trend similar to that in the other samplings, being significantly increased in the ZL treatment. The water soluble fraction of S was significantly higher in the organic treatments (MC, MCZ, and ZL) than with mineral fertilization (MF), while the water soluble fraction of $\mathrm{K}$ was significantly higher in the treatments with compost (MC and MCZ) than in the other two treatments.

\subsection{Evolution of $C$ and $N$ levels during barley culti- vation}

The ANOVA of repeated measures reported significantly higher TOC contents in the soils of treatments $\mathrm{MC}$ and MCZ than in those of MF and ZL at the three sampling times (Figure 2). The TOC content significantly decreased during barley cultivation in the $\mathrm{MC}$ and MCF soils while it was constant in the other treatments. Significantly higher values of TN were observed in MC, MCZ, and ZL than in MF, with a significant decrease in the values of this parameter in the former three treatments with time. Treatment MF gave a lower and constant level of TN in the soil during barley cultivation. For water soluble $\mathrm{C}$ (WSC) and water soluble $\mathrm{N}$ (WSN), greater decreases were observed throughout barley cultivation than for TOC and TN (Figure 2).
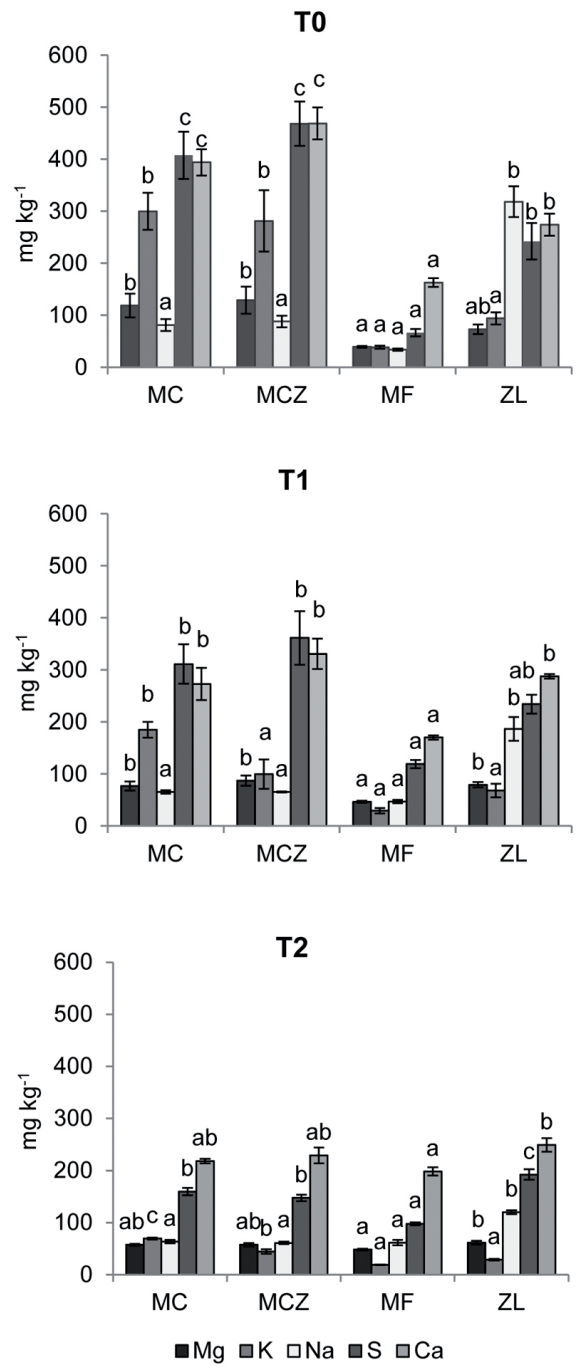

Figure 1. Concentration of main nutrients detected in water soluble fraction of soil with the fertilization treatments at the three sampling times. Error bars represent standard error $(n=4)$.

At samplings T0 and T1, the values of WSN were significantly higher in treatment ZL than in the other three treatments. The nitric-N content underwent a significant decrease throughout the barley cultivation, being significantly higher in the ZL treatment than in the others (Figure 2). 
The ammonium-N content in the soil which received the ZL treatment was significantly higher at the first two sampling times.
Then, it decreased, being similar to that measured in the other treatments at the final soil sampling.
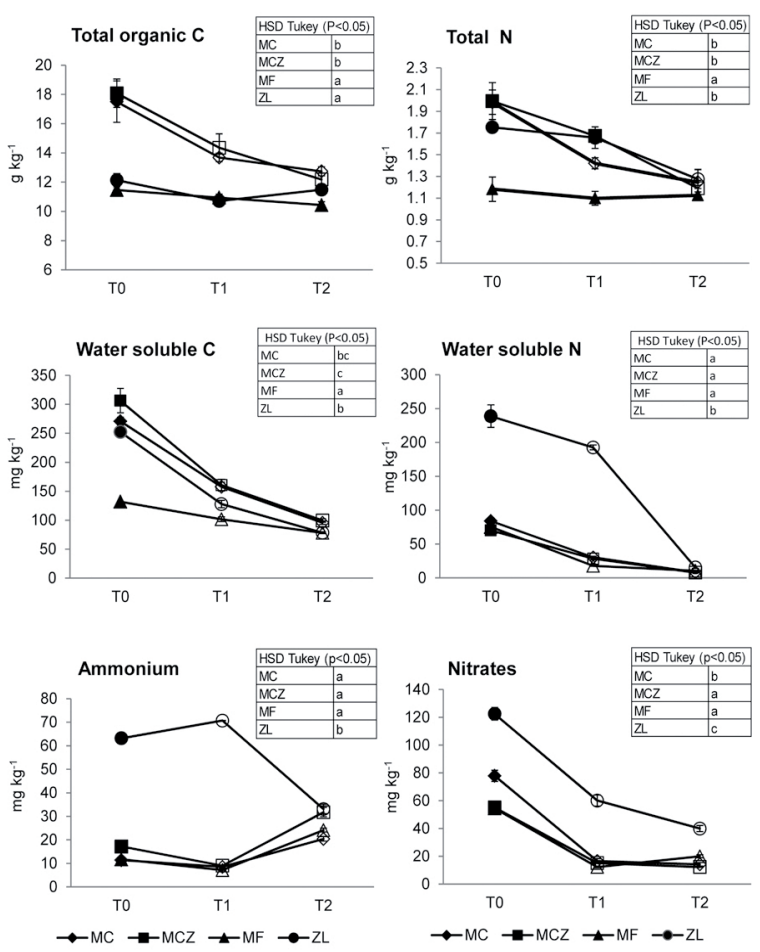

Figure 2. Evolution, throughout barley cultivation, of the concentrations of organic $\mathrm{C}, \mathrm{N}$ and $\mathrm{NO}_{3}^{-}$extracted with water, and $\mathrm{NH}_{4}^{+}$extracted with $1 \mathrm{M} \mathrm{KCl}$ from soil which received the assayed fertilization treatments. For every treatment, empty symbol denotes mean values significantly different $(p<0.05)$ to that registered at sampling time T0. For all sampling times significant differences $(p<0.05)$ between treatments were denoted by not shared letters.

\subsection{Effect of soil treatments on enzyme activi- ties}

In general a decrease in soil enzyme activity, except for soil urease activity (URA), was observed during the barley cultivation, regardless of the basal dressing used (Figure 3). For soil $\beta$-glucosidase activity (BGA), significant differences were not observed between treatments. Soil alkaline phosphatase activity (APA) showed significant differences between the treatment involving amendment with compost and that involving compost supplemented with zeolite, being higher in the former. The two oxidative activities (polyphenol oxidase, PPO, and peroxidase, POD) measured in the soil throughout barley cultivation had similar trends. Thus, significantly higher values of these two enzyme activities were observed with organic amendments (MC, MCZ, and ZL) than with conventional fertilization (MF). The $\mathrm{N}$-acetylglucosaminidase activity (NAG) was significantly higher in the MC and MF treatments, in comparison to treatment $\mathrm{ZL}$, while cellobiohydrolase activity $(\mathrm{CBH})$ was significantly higher in treatments $\mathrm{MC}$ and $\mathrm{MCZ}$ than in MF and ZL, respectively. For leucine aminopeptidase activity (LEU), the values detected in $\mathrm{MC}$ and MF were significantly higher than in ZL and MCZ, respectively. Similar values of urease activity (URA) were measured in MC, MCZ, and MF during the barley cultivation, being significantly higher than that of ZL. 

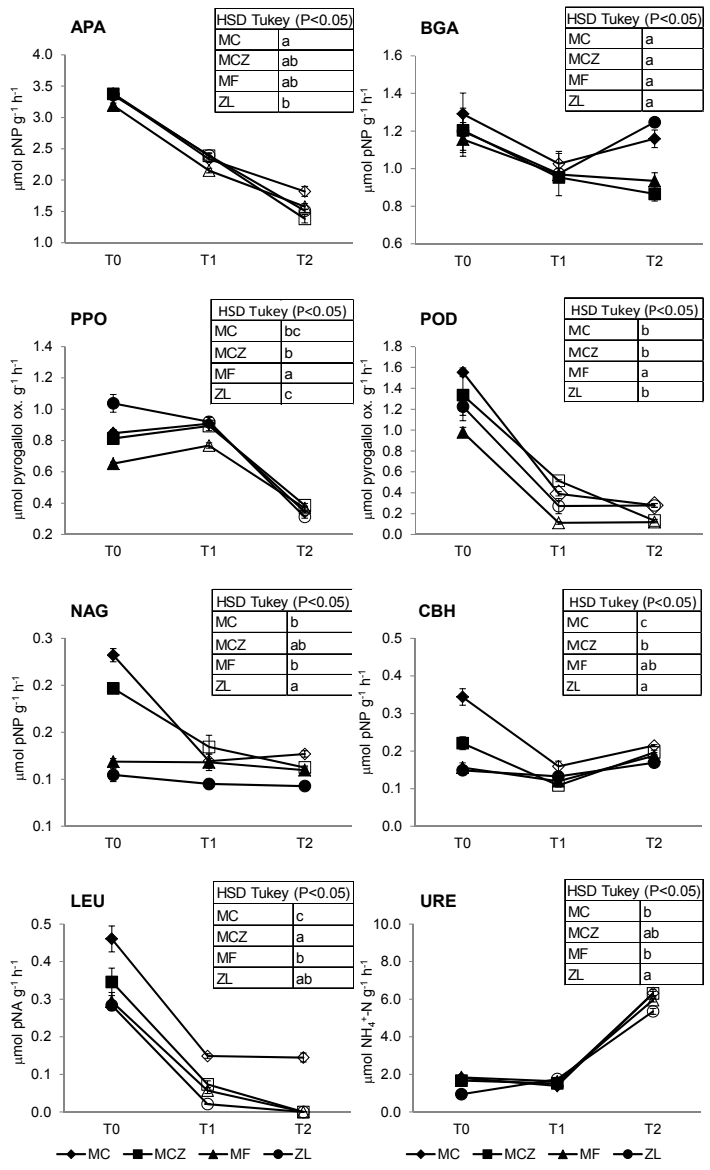

Figure 3. Evolution, throughout barley cultivation, of the enzyme activities measured in soil which received the assayed fertilization treatments. For every treatment, empty symbol denotes mean values significantly different $(p<0.05)$ to that registered at sampling time T0. For all sampling times significant differences between treatments were denoted by not shared letters.

\subsection{The biomass and structure of the soil microbial com- munity, determined by PLFA analysis}

The total PLFA content, as well as the content of PLFA biomarkers of different microbial groups (bacteria, fungi, Gram-positive, Gram-negative, and actinobacteria), tended tended to decrease throughout the barley cultivation, but only in specific cases was this decrease significant. There were no significant differences in total PLFA content among the different treatments assayed. Significantly lower values of bacterial PLFA were detected in treatment $\mathrm{ZL}$, in comparasion to MC (Figure 4)
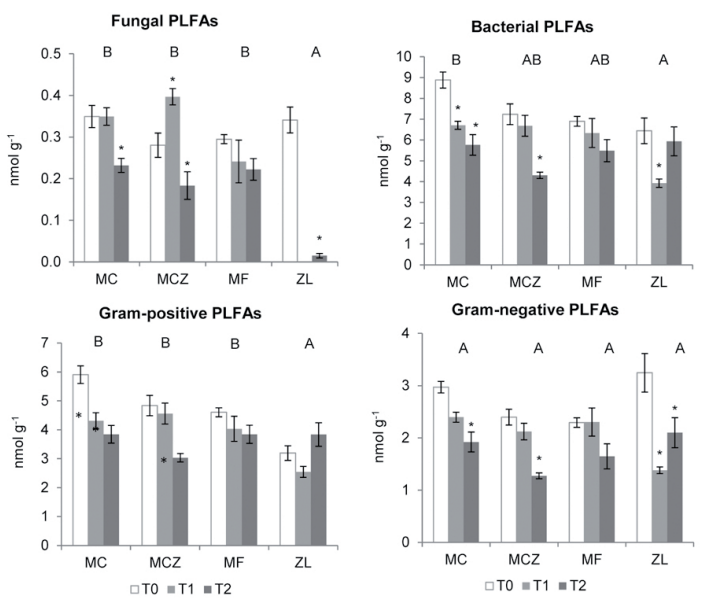

Figure 4. The total PLFA content, as well as the contents of PLFA biomarkers of bacteria, fungi, Gram-positive and Gram-negative measured in soil which received the assayed fertilization treatments at the three sampling times. For every treatment, asterisks above bars denotes mean values significantly different $(p<0.05)$ to that registered at sampling time T0. For all sampling times, significant differences between treatments were denoted by not shared letters above the bars. Error bars represent standard error $(n=4)$

For the fungal and Gram-positive PLFA contents, significant differences among $\mathrm{MC}, \mathrm{MCZ}$, and $\mathrm{MF}$ were not detected, but a significantly lower value was observed in ZL. However, the Gram-negative PLFA content showed no differences among the treatments, although with a tendency to increase in ZL. Using factorial analysis of the PLFA profiles (molar $\%$ of every PLFA biomarker) at the three different soil sampling times, we detected that factor 1 explained 35, 39, and $29 \%$ of the data variability, respectively, for the T0, T1, and T2 samplings, and the second factor 26, 21, and $19 \%$ (Figure 5). 

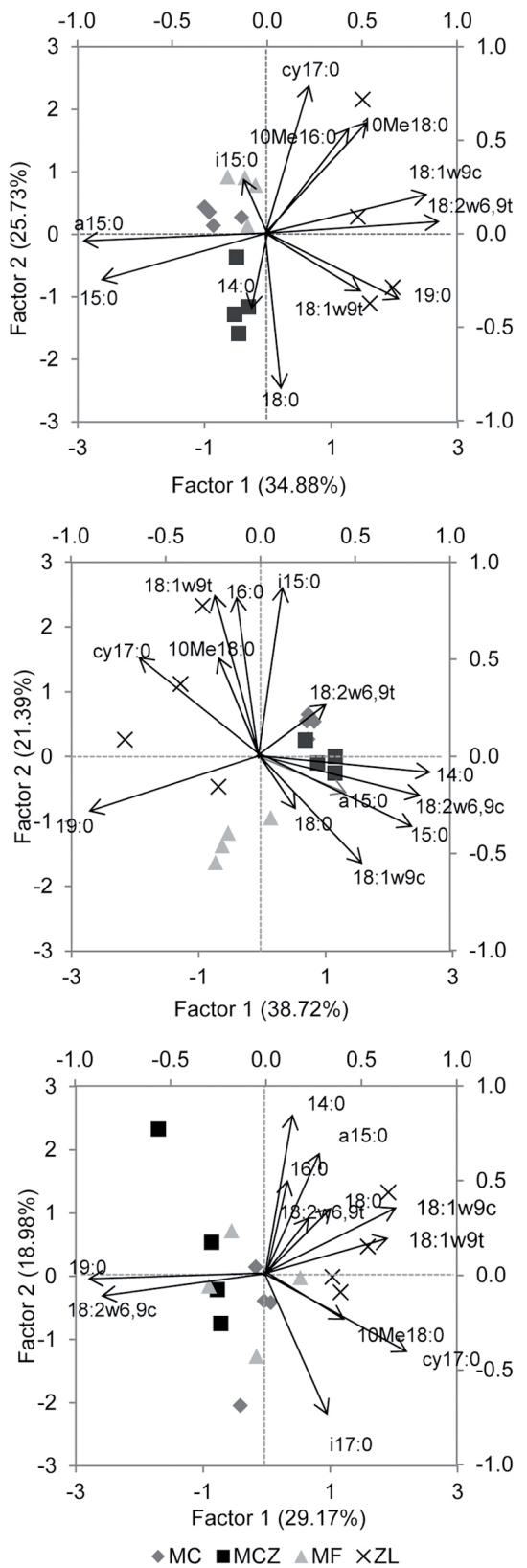

Figure 5. Bi-plots showing similarities or differences, according the Factorial Analysis, between PLFA profiles of microbial communities in soil which received the assayed fertilization treatments, and main correlations of PLFA biomarkers with factor 1 and 2, at every sampling time
Regardless of sampling time, the microbial community structure of soil receiving the treatment $\mathrm{ZL}$ differed significantly $(\mathrm{p}<0.05)$ from that of the other treatments, according to the ANOVA performed on the scores for factor 1 . The simultaneous addition of zeolite with the MC did not influence the microbial community structure, according to the factorial analysis of the PLFA profiles. For the first two sampling times, fungal PLFAs $(18: \omega 26,9 \mathrm{c}$ and $18: 2 \omega 6,9 \mathrm{t})$ had a high and positive correlation with

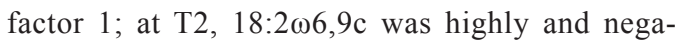
tively correlated with factor 1 .

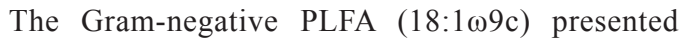
a high correlation with factor 1 at the T0 and $\mathrm{T} 1$ samplings. The Gram-positive biomarker (a15:0) was highly and negatively correlated with factor 1 . At T1, 18:1 19 t (Gram-negative) and i15:0 (Grampositive) presented a high and positive correlation with factor 2, while at T2, i17:0 presented a negative and high correlation with factor 2 .

\subsection{Relationships between soil enzyme activities and soil nutritional status}

Factorial analysis of the data for enzyme activities and the TN, TOC, K, P, and WSC contents in the soil throughout the barley cultivation demonstrated a relationship between the functional capacity of the soil and the nutritional status. Factor 1 explained $47.4,37.9$, and $35.3 \%$ of the data variability, respectively, for the $\mathrm{T} 0, \mathrm{~T} 1$, and $\mathrm{T} 2$ samplings, while factor 2 explained 22.1, 15.9, and $24.9 \%$, respectively (Figure 6). At T0, APA, POD, $\mathrm{CBH}$, NAG, WSC, TN, TOC, and P were highly and positively correlated with factor 1 . However, PPO and URE were highly correlated with factor 2 . 
At T1, POD, URE, NAG, WSC, and TOC were highly correlated, with factor 1, while PPO, APA, and TN were correlated with factor 2 .

At T2, CBH, NAG, URE, WSC, and TOC were highly correlated with factor 1; but, POD, BGA, and PPO were highly correlated with factor 2 . Treatments MC and MCZ had the highest scores for factor 1 and they were significantly different from the other treatments. However, ZL had the highest scores for factor 2 .

3.6. Barley yield and grain quality responses to soil treatments

The harvest index (ratio of grain weight to dry biomass) of the barley crop did not experiment any variation from one soil treatment to another (Figure 7). However, the grain yield (with moisture content of $13 \%$ ) was significantly higher in treatment $\mathrm{ZL}$, in comparison to $\mathrm{MC}$ and $\mathrm{MF}$, and this parameter was not significantly different in the MC, MCZ, and MF treatments.

The quality of grain expressed as the ratio of the $\mathrm{N}$ content in the grain to the $\mathrm{N}$ content in the straw was highest in the treatments with zeolite (MCZ and ZL), being significantly higher than for MF which gave a significantly higher value than MC.
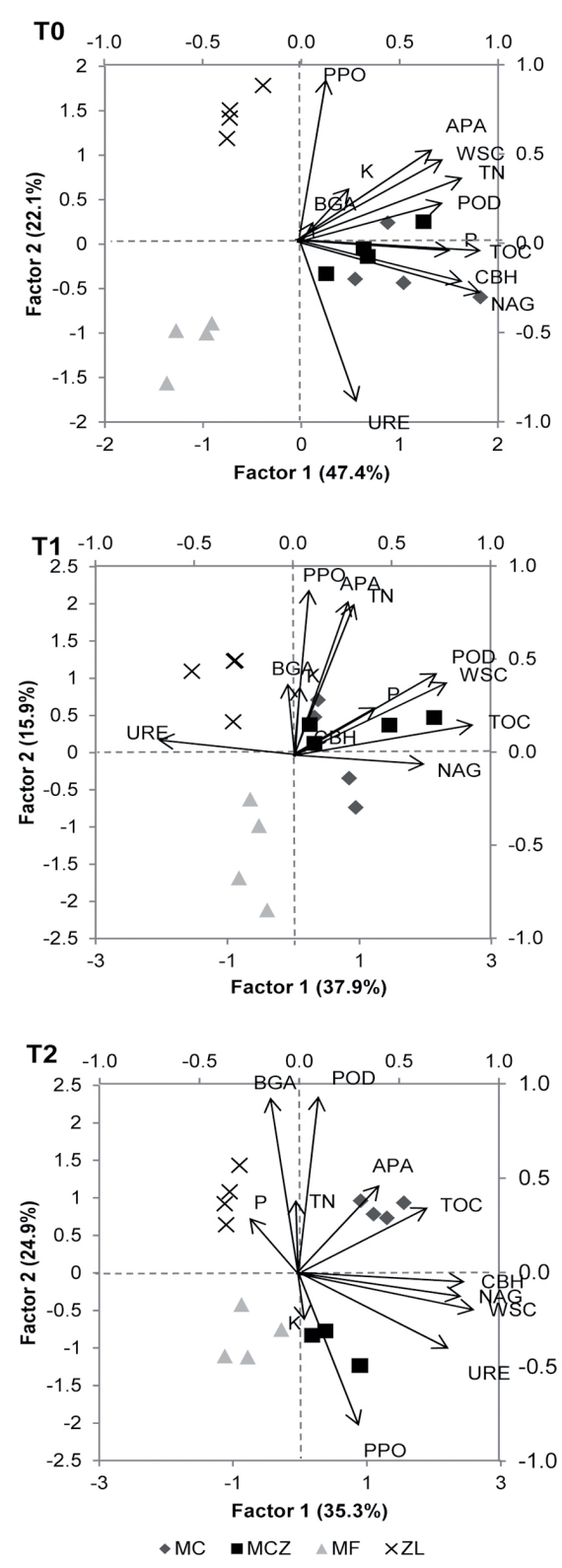

Figure 6. Bi-plots showing similarities or differences between the assayed fertilization treatments according the Factorial Analysis performed on measured values of enzyme activities and nutrients in soil, and main correlations of these variables with factor 1 and 2, at every sampling time. 


\section{Harvest index}

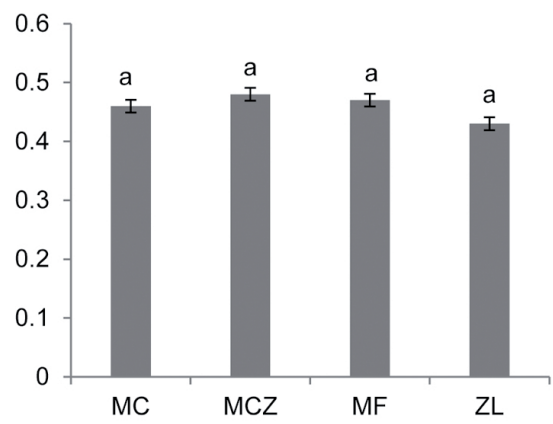

Yield of grain (moisture 13\%)
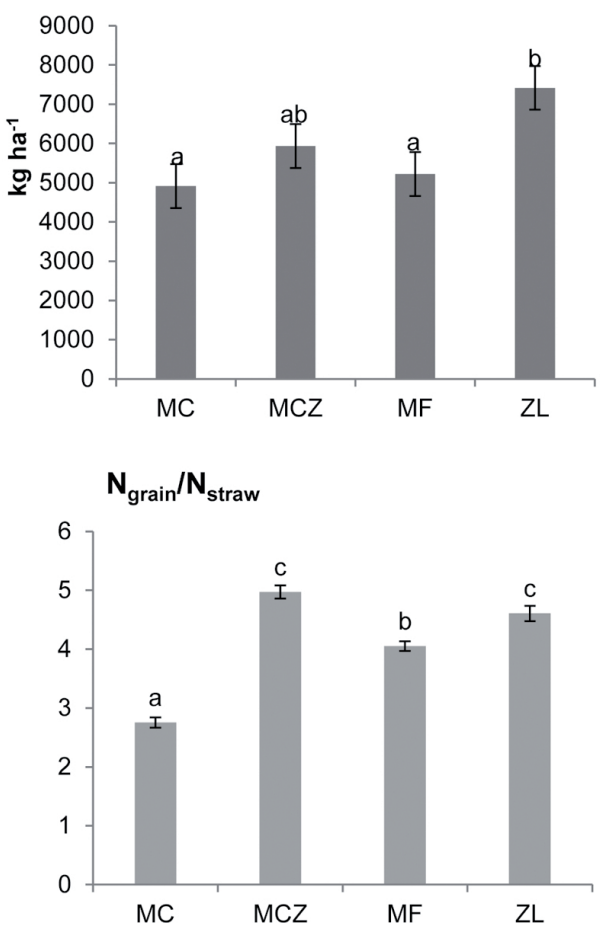

Figure 7. Average value of harvest index (grain to dry biomass weight ratio), yield of grain (moisture $13 \%$ ) and ratio between the $\mathrm{N}$ contents measured in grain and straw of barley. Shared letters above columns denote no significant differences of the values between treatments.

\section{Discussion}

Application of manure compost or zeolite supplemented with leonardite increased soil chemical fertility at the beginning of barley cultivation; particularly, they gave hydro-soluble concentrations of the nutrients in soil that were similar to or higher than with the mineral fertilization conventionally used in barley cultivation. In other studies researchers have found that compost or humic substances from leonardite can be proper substitutes for mineral fertilization in agriculture (Hernandez et al., 2014; Pascual et al., 1997; Flores-Sanchez et al., 2016). In our study, the simultaneous application of zeolite with the compost did not have a significant effect on the total or hydro-soluble fraction of macro and micronutrients, with respect to the addition of compost alone. Other authors have demonstrated positive effects of zeolites on soil (Komaromine et al., 2008; Pinon-Villarreal et al., 2013). Interestingly, the use as an amendment of leonardite mixed with zeolite increased the level of inorganic $\mathrm{N}$ forms (nitrate and ammonium) in soil. According to Sanli et al., (2013), leonardite serves to increase available $\mathrm{N}, \mathrm{P}$, and $\mathrm{K}$ in the soil - which, in turn, could be taken up by plants.

However, this could be a limiting factor in the normal use of ZL in agriculture, in areas having a high risk of nitrate pollution of groundwater, as in the experimental area where this open field trial was developed. This risk derives from the low depth of the water table, which can be as close as $40 \mathrm{~cm}$ to the superficial soil layer, and the agricultural use of land in this area. In this way, excessive accumulation in the soil of these hydro-soluble $\mathrm{N}$ forms may cause water body contamination.

The total concentrations heavy metal $(\mathrm{Cr}, \mathrm{Cu}, \mathrm{Ni}$, and $\mathrm{Pb}$ ) were close to their mean background concentrations commonly reported for different soils (Kabata-Pendias and Mukherjee, 2007) and they did 
not exhibit significant differences between treatments (data not presented).

Regarding the water soluble concentrations of heavy metals in the soil, the agricultural use of the amendments assayed in this experiment will not be limited by their contribution to soil pollution by heavy metals; these soil treatments have been proven as safe and suitable amendments for barley cultivation in open field conditions. However, the higher levels of $\mathrm{Na}$ (total and hydro-soluble) reached in the ZL treatment could limit the frequent use of this amendment in agriculture.

The alternative fertilization practices assayed in this experiment produced increases in the levels of TOC and WSC in the soil, relative to the use of MF. In other studies, improvements of the organic $\mathrm{C}$ content in soil due to the application of compost or leonardite have been reported (Leita et al., 1999; Ondoño et al., 2016; Soler-Rovira et al., 2010), thus enhancing the soil C storage capacity (Bhattacharya et al., 2016; Diacono \& Montemurro, 2010; Smith, 2004). Improvements in WSC with treatments $\mathrm{MC}, \mathrm{MCZ}$, and ZL, relative to conventional fertilization (MF), were observed throughout the barley cultivation, which explain the higher enzymatic activities and microbial biomass found after the application of these fertilization practices. The hydro-soluble fraction of SOC represents a C-substrate pool readily available for nutrient and energy acquisition by soil microorganisms.

Extracellular enzymatic activity (EEA) represents the soil potential for transforming or degrading OM (Gianfreda, 2015). In this study, the hydrolytic enzymes APA, CBH, NAG, and LEU presented significantly higher values in soil amended with compost than in soil receiving conventional fertilization, throughout the barley cultivation, and zeolite addition had no or little effect on these enzyme activities. This fact is due to the higher contribution of compost to the increases in the specific substrates of these enzymes.
Similar findings were observed by other researchers (Reardon \& Wuest, 2016; Ros et al., 2006). Moreover, these initial differences in these enzyme activities of MC soil, with respect to the other treatments, were maintained during barley cultivation; in the case of $\beta$-glucosidase, its initial small difference increased in the last phase of barley crop development. This can be explained because the OM added by MC to soil, in addition to being an enzyme substrate resource, protects enzyme macromolecules in the presence of proteolytic enzymes (Burns et al., 2013; Moreno et al., 2007; Nannipieri, 2006). In the case of $\beta$-glucosidase the increasing difference from other treatments could be explained also by a different evolution of cellulose degradation in the soil amended with $\mathrm{MC}$, producing a gradual accumulation of specific substrates of this enzyme in the last phases of barley cultivation. Extracellular urease activity hydrolyzes urea or ureic compounds to produce ammonium in soil. At the beginning of barley emergence, this enzyme activity was low due to the higher amount of ammonium in the soil and the low demand for this nutrient in this first phase of barley cultivation, which produced an inhibition of urease activity. However, during the next phases of barley growth, from the end of emergence to the beginning of stem extension, an increase in urease activity was observed due to the higher plant demand for available $\mathrm{N}$ and the increasing amounts of specific substrates of this enzyme, produced by gradual SOM degradation. Initially, enzymatic activities with key roles in SOM oxidation - such as polyphenol oxidase and peroxidase - were increased by the addition of both compost (treatments MC and MCZ) and leonardite (ZL) and a significant difference from the conventional treatment (MF) was maintained. Some microorganisms use these two phenol oxidases to degrade lignin and humus, to obtain more labile $\mathrm{C}$ and nutrients (Sinsabaugh, 2010). For these two enzyme activities, the amount of $\mathrm{C}$ in humic substances added 
with the leonardite of the ZL treatment could have had a positive effect. In previous studies, a positive correlation between humic substances and the activities of these phenol oxidases was found (Ondoño et al., 2014). However, the presence of zeolite in these amendments had no significant effect on the activities of these oxidoreductases.

The fertilization treatments induced differences in the biomass of Gram+ bacteria and fungi, which were decreased in $\mathrm{ZL}$ in comparison to the other treatments, while the biomass of Gram- bacteria was increased in ZL. These results indicate a change in the composition of the microbial community as a consequence of the type of fertilizer. Similarly, the microbial community structure was changed in ZL relative to the other treatments, throughout the time of sampling. Cozzolino et al., (2016) and Tejada et al., (2006) reported that the chemical properties of compost used as an amendment may affect the microbial community structure of soil. In our study, different molecular properties of leonardite or, particularly, the properties of the soil amended with ZL i could have altered the soil microbial community structure, relative to the other treatments. Interestingly, Gram-negative and fungal biomarkers were among the fatty acids that explained to a great extent the differences in the structure of the microbial community at T2. Precisely, we found that Gram-negative and fungal PLFAs were highly and positively correlated to WSC, being their Spearman correlation coefficients 0.581 and 0.630 respectively at $\mathrm{P}<0.05$ (data not presented). For instance, the Gram- bacteria include those of the phylum Proteobacteria that are mainly considered as copiotrophic organisms; that is, with the ability to grow quickly when energy and carbon sources are available, such as those contained in WSC (Bastida et al., 2016; Fierer et al., 2007). In this case, it could be hypothesized that ZL promoted a change to a more copiotrophic community through the increases in WSC and WSN. Indeed, ZL contained a higher amount of soluble organic matter.

\section{Conclusions}

In this field experiment with a barley crop, the alternative fertilization treatments tested had an overall positive effect, in comparison with conventional fertilization with a mineral NPK fertilizer, when soil quality parameters, the nutritional level of the barley grain and straw, and crop yield were analyzed. There were relationships between the soil levels of water soluble $\mathrm{C}$ and $\mathrm{N}$, extracellular enzyme activities, microbial community structure, and barley yield according to the different fertilization treatments applied as a basal dressing; these relationships were maintained throughout the barley cultivation. In general, fertilization with compost or the humic extract of leonardite, regardless of the zeolite content, met the nutritional requirements of the barley plants and only a quarter of the mineral fertilization dose, as a top dressing, was necessary to obtain a yield similar to or higher than that of the conventional mineral fertilization. In addition, these alternative fertilization treatments improved soil quality throughout the barley cultivation cycle; hence, the soil conditions remained better for the following crop.

The treatment involving zeolite enriched with the humic extract of leonardite increased barley yield in comparison with the compost treatments, either with zeolite or without, but had a negative characteristic, namely, an excessive contribution to the water soluble contents of $\mathrm{Na}$ and $\mathrm{N}$ in soil, which can limit its use in agricultural areas with a risk of nitrate contamination of groundwater. In addition, this leonardite-enriched zeolite has the disadvantage, compared to compost, that for its manufacture the exploitation of limited resources is necessary, which in turn results in a higher price of this amendment in comparison to compost. 
By contrast, composting involves the addition of value to organic wastes, in this case manures from sheep and goats, transforming them into an organic fertilizer product free of elements harmful to the soil or pathogens that affect crops or humans. Therefore, the use of compost in agriculture will encourage the decreased use of conventional fertilizers, whose manufacture requires the exploitation of more mineral and energy resources. So, using environmental and agronomic criteria, the most rational action would be the use of compost in agriculture to a greater extent than conventional fertilizers.

\section{Acknowledgements}

The authors are grateful to National Institute for Agricultural and Food Research and Technology (INIA) of Spanish Ministry of Economy and Competitiveness, and ERANET-ARIMNET programme for funding this study as a work action inside the project ARIDWASTE (Ref. number: 219262 FP7-ERANET ARIMNET) entitled: "Development of Specific Agricultural Practices with the Use of Recycled Wastes Suitable for Intensively Cultivated Mediterranean Areas under Degradation Risk". The authors also are grateful to Dr David J. Walker from Instituto Murciano de Investigación y Desarrollo Agroalimentario, Murcia, Spain for his language edition and writing assistance in this paper.

\section{References}

Allison, S.D., Jastrow, J.D. 2006. Activities of extracellular enzymes in physically isolated fractions of restored grassland soils. Soil Biol. Biochem. $38,3245-3256$.

Ayuso, M., Moreno, J.L., Hernandez, T., Garcia, C. 1997. Characterisation and evaluation of humic acids extracted from urban waste as liquid fertilisers. J. Sci. Food Agr. 75, 481-488.

Baath, E., Anderson, T.H. 2003. Comparison of soil fungal/bacterial ratios in a $\mathrm{pH}$ gradient using physiological and PLFA-based techniques. Soil Biol. Biochem. 35, 955-963.

Bastida, F., Kandeler, E., Moreno, J.L., Ros, M., García, C., Hernandez, T. 2008. Application of fresh and composted organic wastes modifies structure, size and activity of soil microbial community under semiarid climate. Appl. Soil Ecol. 40, 318329.

Bhattacharya, S.S., Kim, K.H., Das, S., Uchimiya, M., Jeon, B.H., Kwon, E., Szulejko, J.E. 2016. A review on the role of organic inputs in maintaining the soil carbon pool of the terrestrial ecosystem. J. Environ. Manage. 167, 214-227.

Bligh, E., Dyer, W. 1959. A rapid method of total lipid extraction and purification. Can. J. Biochem. Phys. 37, 911-917.

Burns, R.G., De Forest, J.L., Marxsen, J., Sinsabaugh, R.L., Stromberger, M.E., Wallenstein, M.D., Weintraub, M.N., Zoppini, A. 2013. Soil enzymes in a changing environment: Current knowledge and future directions. Soil Biol. Biochem. 58, 216-234.

Cozzolino, V., Di Meo, V., Monda, H., Spaccini, R., Piccolo, A. 2016. The molecular characteristics of compost affect plant growth, arbuscular mycorrhizal fungi, and soil microbial community composition. Biol. Fert. Soils. 52, 15-29.

Diacono, M., Montemurro, F. 2010. Long-term effects of organic amendments on soil fertility. A review. Agron. Sustain. Dev. 30, 401-422.

Frostegard, A., Baath, E., Tunlid, A. 1993. Shifts in the structure of soil microbial communities in limed forests as revealed by phospholipid fattyacid analysis. Soil Biol. Biochem. 25, 723-730. 
Gianfreda, L. 2015. Enzymes of importance to rhizosphere processes J. Soil Sci. Plant Nutr. 15, 283-306.Hernandez, T., Chocano, C., Moreno, J. L., Garcia, C. 2014. Towards a more sustainable fertilization: Combined use of compost and inorganic fertilization for tomato cultivation. Agr. Ecosyst. Environ. 196, 178-184.

Komaromine, M.K., Loksa, G., Csereklye, K.E., Bardoczyne, E.S., Kallai, S. 2008. Use of zeolite to improve soil amelioration and takes effects on microclimate. Cereal Res. Commun. 36, 1783-1786.

Leita, L., De Nobili, M., Mondini, C., Muhlbachova, G., Marchiol, L., Bragato, G., Contin, M. 1999. Influence of inorganic and organic fertilization on soil microbial biomass, metabolic quotient and heavy metal bioavailability. Biol. Fert. Soils. 28, 371-376.

Moreno, J.L., Jindo, K., Hernandez, T., Garcia, C. 2007. Total and immobilized enzymatic activity of organic materials before and after composting. Compost Sci. Util. 15, 93-100.

Nannipieri, P. 2006. Role of stabilised enzymes in microbial ecology and enzyme extraction from soil with potential applications in soil proteomics. In: P. Nannipieri and K. Smalla (eds.). Nucleic Acids and Proteins in Soil, Volume 8, Soil Biology Series. Springer, Berlin Heidelberg, pp. 75-94.

Ondoño, S., Bastida, F., Moreno, J.L., 2014. Microbiological and biochemical properties of artificial substrates: A preliminary study of its application as Technosols or as a basis in Green Roof Systems. Ecol. Eng. 70, 189-199.

Ondoño, S., Martinez-Sanchez, J.J., Moreno, J.L. 2016. The composition and depth of green roof substrates affect the growth of Silene vulgaris and Lagurus ovatus species and the $\mathrm{C}$ and $\mathrm{N}$ sequestration under two irrigation conditions. J. Environ. Manage. 166, 330-340.
Pascual, J. A., Ayuso, M., Hernandez, T., Garcia, C. 1997. Phytotoxicity and fertilizer value of different organic materials. Agrochimica. 41, 50-62.

Pinon-Villarreal, A.R., Bawazir, A.S., Shukla, M.K., Hanson, A.T. 2013. Retention and Transport of Nitrate and Ammonium in Loamy Sand Amended with Clinoptilolite Zeolite. J. Irrig. Drain. Eng. 139, 755-765.

Polat, E., Karaca, M., Demir, H., and Naci-Onus, A. 2004. Use of natural zeolite (clinoptilolite) in agriculture. J. Fruit Ornam. Plant Res. 12, 183-189.

Reardon, C.L., Wuest, S.B. 2016. Soil amendments yield persisting effects on the microbial communities-a 7-year study. Appl. Soil Ecol. 101, 107116.

Ros, M., Pascual, J.A., Garcia, C., Hernandez, M.T., Insam, H. 2006. Hydrolase activities, microbial biomass and bacterial community in a soil after long-term amendment with different composts. Soil Biol. Biochem. 38, 3443-3452.

Sanli, A., Kradogan, T., Tonguc, M. 2013. Effects of leonardite applications on yield and some quality parameters of potatoes (Solanum tuberosum L.). Turk. J. Field Crops. 18, 20-26.

Sinsabaugh, R. 2010. Phenol oxidase, peroxidase and organic matter dynamics of soil. Soil Biol. Biochem. 42, 391-404.

Smith, P. 2004. Carbon sequestration in croplands: the potential in Europe and the global context. Eur. J. Agron. 20, 229-236.

Soler-Rovira, P., Madejon, E., Madejon, P., Plaza, C. 2010. In situ remediation of metal-contaminated soils with organic amendments: Role of humic acids in copper bioavailability. Chemosphere. 79, 844-849. 
Tejada, M., Hernandez, M.T., Garcia, C., 2006. Application of two organic amendments on soil restoration: Effects on the soil biological properties. J. Environ. Qual. 35, 1010-1017.
Wells, A.T., Chan, K.Y., Cornish, P.S. 2000. Comparison of conventional and alternative vegetable farming systems on the properties of a yellow earth in New South Wales. Agr. Ecosyst. Environ. $80,47-60$ 